\title{
Spring and early summer species of Cortinarius, subgenus Telamonia, section Colymbadini and /Flavobasilis, in the mountains of western North America
}

\author{
Authors: Joseph F. Ammirati, Tuula Niskanen, Kare \\ Liimatainen, Dimitar Bojantchev, Ursula Peintner, Regina \\ Kuhnert-Finkernagel, and Cathy Cripps
}

This is an Accepted Manuscript of an article published in Mycologia on September 2017, available online: http://www.tandfonline.com/10.1080/00275514.2017.1349468.

Ammirati, Joseph F. , Tuula Niskanen, Kare Liimatainen, Dimitar Bojantchev, Ursula Peintner, Regina Kuhnert-Finkernagel, and Cathy Cripps. "Spring and early summer species of Cortinarius, subgenus Telamonia, section Colymbadini and /Flavobasilis, in the mountains of western North America." Mycologia 109, no. 3 (September 2017): 443-458. DOI:

10.1080/00275514.2017.1349468.

Made available through Montana State University's $\underline{\text { ScholarWorks }}$

scholarworks. montana.edu 


\title{
Spring and early summer species of Cortinarius, subgenus Telamonia, section Colymbadini and /Flavobasilis, in the mountains of western North America
}

\author{
Joseph F. Ammiratia, Tuula Niskanen $\mathbb{1}^{\mathrm{b}}$, Kare Liimatainen $\mathbb{1}^{\mathrm{c}}$, Dimitar Bojantchev ${ }^{\mathrm{d}}$, Ursula Peintnere, \\ Regina Kuhnert-Finkernagele, and Cathy Cripps (1) ${ }^{f}$ \\ aDepartment of Biology, University of Washington, Box 351800, Seattle, Washington 98195-1800; 'bodrell Laboratory, Royal Botanic Gardens, \\ Kew, Surrey TW9 3AB, United Kingdom; 'Department of Biosciences, Plant Biology, Department of Biosciences, University of Helsinki, P.O. \\ Box 65, Fl-00014, Helsinki, Finland; 345 Shipwatch Lane, Hercules, California 94547; elnstitute of Microbiology, University Innsbruck, \\ Technikerstraße 25, 6020 Innsbruck, Austria; fDepartment of Plant Sciences and Plant Pathology, Montana State University, 119 Plant \\ Biosciences Building, Bozeman, Montana 59717-3150
}

ABSTRACT

Seven species of Cortinarius, subgenus Telamonia, section Colymbadini and /Flavobasilis, are reported from conifer forests in the mountains of western North America. They typically produce basidiomes in the spring and summer. Only one species, $C$. colymbadinus, is widespread, occurring in Europe and western North America, but to date not reported from California. Cortinarius bridgei, C. flavobasilis, C. rumoribrunsi, C. vernalishastensis, and C. vernalisierraensis are new species. The first two are found throughout the western mountains, whereas the latter three thus far are known only from California. Cortinarius ahsii, a common species in the Rocky Mountains and Pacific Northwest, also has not been recorded from California.
ARTICLE HISTORY

Received 14 February 2017

Accepted 28 June 2017

\section{KEYWORDS}

Agaricales; Cortinariaceae;

snowbank fungi; Telamonia

\section{INTRODUCTION}

In north temperate continental regions, species of Cortinarius (Pers.) Gray typically produce basidiomes in the late summer and autumn, with many fewer species reproducing in the spring and early summer months (Knudsen and Vesterholt 2012). More specifically, in western North America, many unique agarics and other macrofungi reproduce in montane conifer forests during the spring and early summer, often in or near melting snowbanks, and in moist areas following snowmelt (e.g., Cooke 1944, 1955; Miller 1965; Smith 1975; Redhead et al. 2000; Moser 2004; Cripps 2009). The species of Cortinarius found in these habitats have evolved in multiple lineages across the genus and together represent the largest number of ectomycorrhzial macrofungi occurring during this time of the year (Smith 1944; Thiers and Smith 1969; McKnight 1975; Ammirati and Smith 1977; Seidl 2000; Moser and Miller 2002; Ammirati et al. 2012; Bojantchev 2013; Niskanen et al. 2013). In the Rocky Mountains and other higher-elevation mountains of western North America, these early species often occur with a series of species that reproduce throughout the summer season depending on rate of snowmelt and summer thunder showers (Moser 1993, 2002; Moser et al. 1995; Moser and Ammirati 1999).

Cortinarius, subgenus Telamonia (Fr.) Trog, has the largest number of vernal and early summer species, a number of which are found in the section Colymbadini s. lato (McKnight 1975; Moser and Miller 2002; Ammirati et al. 2012; Bojantchev 2013; Niskanen et al. 2013; Dima et al. 2014). Some of these species, now placed in Telamonia, section Colymbadini Melot, were previously classified in Cortinarius, subgenus Leprocybe Moser, because of their yellow-green fluorescent pigments leprocybin and leprocyboside. These pigments are shared with species in section Leprocybe Moser (= section Veneti Korad \& Maubl.) (Gill and Steglich 1987; Peintner et al. 2004).

In this treatment, we provide additional observations on Cortinarius colymbadinus Fr., which occurs during the spring and summer in western North America and Europe (Dima et al. 2014). Also, additional comments are provided for Cortinarius ahsii McKnight, a common species in the mountains of western North America from early spring into summer (McKnight 1975). All other taxa presented here are described as new species, although one of them, C. flavobasilis, already was given a provisional name by Moser and 
Miller (2002). These include Cortinarius bridgei, C. flavobasilis, C. rumoribrunsi, C. vernalishastensis, and C. vernalisierraensis. Interpretation of the names Cortinarius isabellinus (Batsch) Fr. and C. zinziberatus (Scop.: Fr.) Fr. remains unclear; therefore, they are here treated as synonyms of $C$. colymbadinus.

\section{MATERIALS AND METHODS}

Morphological study.-Macroscopic descriptions were made from fresh basidiomes. Color notations are from the Munsell soil color charts (e.g., 5YR3/4; Munsell 1992), Ridgway's color standards and color nomenclature (e.g., Ochraceous-Tawny; Ridgway 1912), or the Reinhold Color Atlas (e.g., 5F6; Kornerup and Wanscher 1962). The colors of exsiccatae were recorded using a full spectrum (Ottlite) lamp. Ultraviolet (UV) recordings were made on fresh and dried basidiomes using a $366 \mathrm{~nm}$ UV lamp. The UV patterns are the same for fresh basidiomes and exsiccatae. $\mathrm{KOH}$ (3-40\% solutions) reactions were made on fresh specimens. Microscopic characteristics are primarily taken from air-dried specimens. Dextrinoid basidiospore reactions were made from pieces of lamellae soaked in Melzer's reagent for 5 min. Lamella hyphae were examined for encrusting pigment in Melzer's reagent, water, and 3\% $\mathrm{KOH}$. Basidiospore measurements were made in $3 \% \mathrm{KOH}$ from basidiospores on lamella surfaces, and those deposited on the stipe apex and veil tissue. Basidiospore measurements in parentheses (e.g., (10)) are exceptional. For $Q$ values, the length divided by width ratios were determined for each of 30 randomly selected spores, 10 each from three different collections. The $\mathrm{Q}$ values for individual spores provide the range and are used to calculate a mean $\mathrm{Q}$ value. The 'Additional specimens examined' are those examined morphologically with no molecular data (see SUPPLEMENTARY DATA). Herbaria designations follow Thiers (continuously updated).

\section{DNA extraction, PCR amplification, and sequencing.}

- Thirty-four sequences from eight species were produced for this study. DNA was extracted from dried material (pieces of lamellae) with the NucleoSpin Plant kit (Macherey-Nagel, Düren, Germany). For some specimens, Phire Plant Direct PCR kit (Thermo Fisher Scientific, Waltham, Massachusetts, USA) was used for DNA extraction and polymerase chain reaction (PCR) according to the manufacturer's protocol. Primers ITS-1F and ITS 4
(White et al. 1990; Gardes and Bruns 1993) were used to amplify the internal transcribed spacer (ITS) rDNA regions (ITS1-5.8S-ITS2 = ITS), and the same primer pairs were used in direct sequencing. PCR amplification and sequencing followed Liimatainen et al. (2014).

Data analyses.-Sequences were assembled and edited with sequencher 4.1 (Gene Codes, Ann Arbor, Michigan, USA). For phylogenetic analysis, our own as well as already published sequences of the section Colymbadini s. lato, and closely related Uracei s. lato and Cinnabarini s. lato, were included. The group was shown to be monophyletic, with a bootstrap support value of $98 \%$ in Garnica et al. (2016). Two of our sequences were excluded from analyses because of the incomplete end of the ITS 2 region. Incomplete ITS sequences might have an effect on the topology of the phylogenetic tree because differences are small in some groups. Section Armillati Moser and subgenus Dermocybe (Fr.) Trog were chosen as outgroups based on the phylogeny of Peintner et al. (2004). The ITS alignment of 72 sequences was produced with the program MUSCLE (Edgar 2004) under default settings. The alignment was manually adjusted in SEAVIEW (Galtier et al. 1996). The alignment is composed of 664 nucleotides (including gaps) and is available at TreeBASE under S19997 (http://www.treebase.org/tree base-web/home.html). Sequences were subjected to maximum likelihood (ML) analysis as implemented in RAxML 8 (Stamatakis 2014), with 1000 bootstrap replicates under the GTRGAMMA model.

\section{RESULTS}

Molecular data. - The phylogenetic tree resulting from our analysis is shown in FIG. 1. Cortinarius ahsii, $C$. colymbadinus, and C. vernalisierraensis were placed in section Colymbadini. Cortinarius bridgei, C. flavobasilis, C. rumoribrunsi, and C. vernalishastensis formed a separate clade, /Flavobasilis, but without support, and consequently their relationships within the Colymbadinil Uracei/Cinnabarini clade remain unresolved.

All studied species did not receive high support values, and some intrasection/clade relationships remain unresolved. Some species are genetically close to one another, and a major part of the genetic differences often comes from insertions and deletions (indels), which may explain the poor recovery of some species and groups in the analysis. However, for all of the species, the intraspecific variation is clearly smaller than the interspecific difference (barcoding gap). 


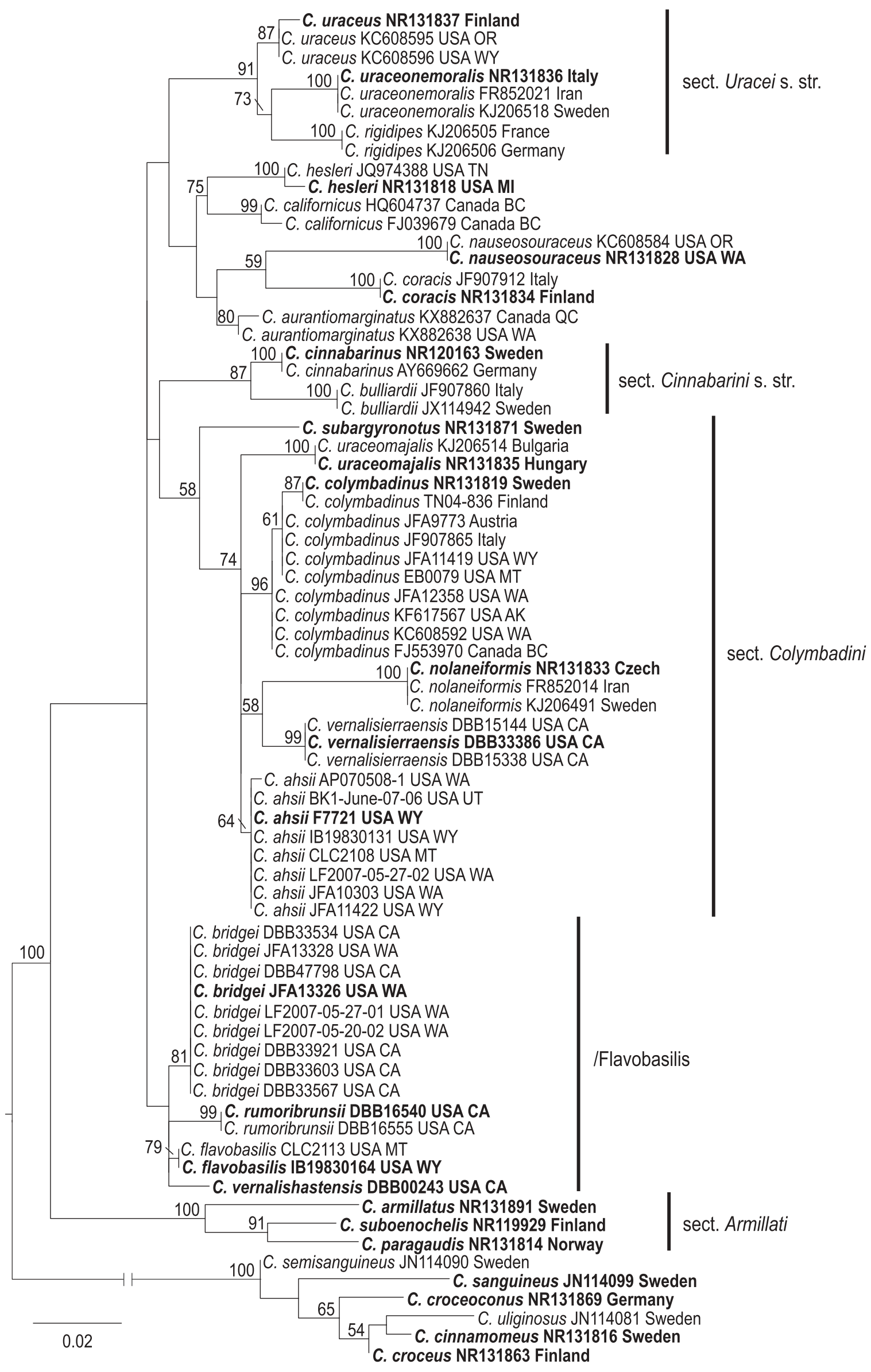

Figure 1. Phylogram resulting from the RaXML analysis of ITS regions. Bootstrap values greater than $50 \%$ are indicated above branches. Sequences originating from the type specimens of the species are in boldface. 


\section{TAXONOMY}

\section{Cortinarius, subgenus Telamonia, section} Colymbadini Melot

Type species: Cortinarius colymbadinus Fr.

Medium-sized, more or less brown species usually with a cylindrical stipe. Universal veil often sparse. Basidiospores rather small (on average $<9.5 \times 4.5-5.5 \mu \mathrm{m}$ ), amygdaloid, surface moderately to strongly verrucose. Clamp connections present. All species with a positive yellow UV reaction, except in European C. uraceomajalis it is occasionally orange. Typically producing basidiomes in spring and summer. Widespread and known from western North America to Eurasia.

Cortinarius ahsii McKnight, Beih Nova Hedwigia 51:177. 1975. FIGS. 2C, D, 4A
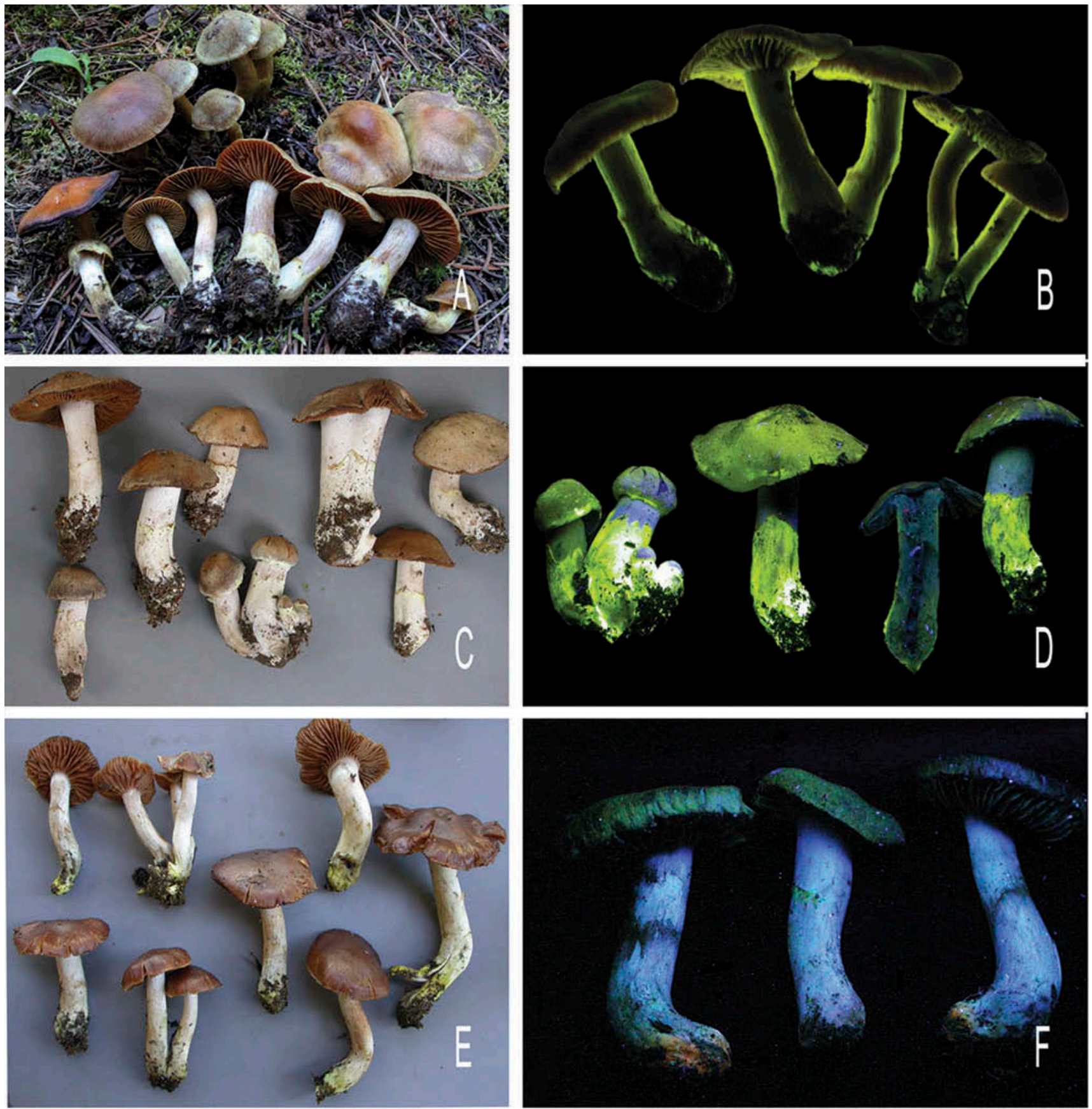

Figure 2. Basidiocarps in natural and UV light. A-D. Section Colymbadini. A, B. Cortinarius colymbadinus (EB0079). C, D. C. ahsii (CLC2108). E, F. /Favobasilis clade. E. C. flavobasilis (CLC2113) in natural light. F. C. bridgei (CLC2105) in UV light. 
Typification: USA. WYOMING: Teton Co., Grand Teton National Park, Jackson Lake Camp, on soil under Lodgepole Pine (Pinus contorta), 9 Jun 1965, K.H., J.B., and L.B. McKnight, F7721 (holotype BRY). Isotype IB19650703. GenBank: ITS = KX882644.

= "Cortinarius flavoroseus" nomen nudem, M.M. Moser \& O.K. Miller, Cortinarius species from the snowbanks in the Rocky Mountains. Unpublished manuscript, 23 p. (2002).

Description: Pileus $20-70 \mathrm{~mm}$ diam, broadly campanulate to umbonate, expanding to broadly convex or plane, umbo flat or rounded, margin incurved at first, moist, hygrophanous, nonstriate or only faintly striate at edge, glabrous to minutely fibrillose, color dark reddish brown (5YR5/4, Verona Brown or slightly Natal Brown), moderate reddish brown (2.5YR3/4), or dark brown (5YR4/8) to light brown (7.5YR5/4), sometimes lighter and more yellowish on disc (near Tawny Olive), fading to light yellowish brown (10YR7/4) with drying, sometimes with greenish yellow veil fibrils near margin. Lamellae narrowly adnate to adnexed, subdistant, thin to moderately thick, rarely fused, warm ochraceous brown to rich brown becoming rusty brown, edges even and pale to concolorous. Stipe 35-60 mm long, 5-15 mm thick, equal or slightly expanded at base, often contorted, surface fibrillose, buff to light brown (lighter than pileus) or light to pale brown (Rood's Brown), streaked with white above, with one or more zones of greenish yellow fibrillose universal veil remnants at midstipe or lower, often with conspicuous rhizomorphs at the base. Universal veil yellow (Massicot Yellow, Straw Yellow, Amber Yellow). Context of pileus thin, concolorous with pileus surface; solid in stipe, light brown or darker brown in base. Odor lacking or faint and aromatic, taste not distinctive, fungoid. Exsiccatae: pileus light brown to brown or blackish, surface sometimes with a pale reflection; lamellae rich brown to blackish; stipe pale to grayish or light brown to darker brown with some blackish areas above, below pale to whitish or creamy to yellowish from universal veil, base whitish to pale yellow; context pale to brownish or somewhat blackish.

UV fluorescence: universal veil covering on stipe and pileus surfaces or sometimes only the stipe base bright yellow. KOH (10\%): red on universal veil.

Basidiospores 7.3-9.6 $\times 4.4-5.2 \mu \mathrm{m}$, avg. $8.3 \times 4.7$ $\mu \mathrm{m}, \mathrm{Q}=1.5-1.9$, avg. Q 1.7, \pm amygdaloid to ellipsoidal, surface moderately to coarsely verrucose, slightly to strongly dextrinoid. Basidia 4-spored, $25-34 \times 7.5-10$ $\mu \mathrm{m}$, clavate, colorless or with yellowish to brownish contents. Lamella trama hyphae smooth to strongly encrusted. Pileipellis: a layer of veil hyphae typically covering the surface of the pileus margin; epicutis hyphae cylindrical, mostly $2-8 \mu \mathrm{m}$ wide, colorless or slightly yellowish, occasionally encrusted; hypocutis moderately developed, hyphae cylindrical to enlarged, 4-20 $\mu \mathrm{m}$ wide, colorless to brownish, more brownish adjacent to pileus trama, smooth to encrusted, with scattered brown pigment masses; pileus trama colorless to brownish.

Ecology and distribution: In soil and litter of conifer forests, solitary to gregarious or caespitose. Common and sometimes locally abundant; basidiomes produced in early spring and summer, associated with snowbanks, but also found shortly after snow melt. Known from southwest Montana, southeast Utah to northwest Wyoming, the Olympic Mountains of Washington and the Cascade Mountains of Washington and northern Oregon. Not recorded from California.

Specimens examined: USA. MONTANA: Madison Co., Gravelly Mountains, Pinus albicaulis Engelm, Abies, Picea, 6 Jul 2005, C. Cripps, CLC2108 (MONT), GenBank: KX882645. UTAH: Morgan Co., Utah State University Forest, Pinus, Abies, 7 Jun 2006, B. Kropp, BK1-June-07-06 (UTC), GenBank: KX882646. WASHINGTON: Kittitas Co., Table Mountain, Pseudotsuga, Abies, Pinus contorta, Picea, Larix, Tsuga, 5 Jul 2007, L. Fang, LF2007-05-27-02 (WTU), GenBank: KX882647; Pend Oreille Co., Boundary Dam overlook road, Thuja, Abies, Tsuga, Larix, Betula, 7 May 2008, A. Parker, AP070508-1 (WTU), GenBank: KX882648; Skagit Co., Easy Pass trailhead, in soil and humus, mixed conifers, Abies, Tsuga, Pseudotsuga, Picea, Pinus spp., 2 Jul 1991, J. Ammirati, JFA10303 (WTU), GenBank: KX882649. WYOMING: Carbon Co., Medicine Bow Mountains, Silver Lake, mixed conifers, Abies, Picea, Pinus, 27 Jul 1987, M.M. Moser, IB19830131 (IB), GenBank: KX882650; Teton Co., Two Oceans Mountains, subalpine, Picea, Pinus, Vaccinium, in soil and humus, 28 Aug 1995, J. Ammirati, JFA11422 (WTU), GenBank: KX882651.

Notes: Cortinarius ahsii was named after Alexander Hanchett Smith (McKnight 1975). Typically C. ahsii is UV+ yellow on the universal veil, usually seen on the stipe and pileus surfaces, and the stipe base; however, occasionally only the stipe base is UV+ yellow. Cortinarius colymbadinus has a more extensive UV+ yellow reaction, including the stipe, 
universal veil, pileus, lamella edges, and context. In the original description, McKnight (1975) gives a brief discussion of $C$. ahsii, including a comment that one of the tested collections was entirely UV+ yellow. This is probably C. colymbadinus. McKnight (1975) made extensive measurements of basidiospores from the type collection and reported them as 6.6-8.8 $\times 4.4 \mu \mathrm{m}$ with an average basidiospore length of 7.4 $\mu \mathrm{m}$. On the other hand, he published the basidiospore measurements for C. ahsii as (6.5-)7.5-9.5(-11) $\times$ (3.5-)4.5-5.5(-6) $\mu \mathrm{m}$, somewhat larger than reported here, and may have included measurements for $C$. colymbadinus in that range, which tends to have larger spores. In the ITS regions, C. ahsii differs from the other known western North American species of section Colymbadini as follows: C. vernalisierraensis by $8(1.5 \%)$ and C. colymbadinus by $10(1.9 \%)$ substitution and indel positions. For further comparison, see notes under these taxa.

Additional specimens examined: See SUPPLEMENTARY DATA.

Cortinarius colymbadinus Fr., Epicr Syst Mycol: 289. 1838.

FIGS. 2A, B, 4B

Mycobank MB198355

Typification: SWEDEN. JÄMTLAND: Ragunda, Kullstabodarna, in rich spruce forest, 16 Aug 1992, T.E. Brandrud, H. Lindström, H. Marklund, and S. Muskos, CFP1130, F248443 (neotype S). GenBank: ITS $=$ JX127302.

$=$ Cortinarius isabellinus $($ Batsch $)$ Fr. sensu Brandrud et al. (1998).

$=$ Cortinarius zinziberatus (Scop.: Fr.) Fr. sensu Moser (1978).

Description: Pileus $\quad 30-80 \mathrm{~mm}$ diam, obtusely rounded to broadly obtuse becoming irregularly obtuse-convex, uneven, slightly subumbonate but disc typically flattened to somewhat depressed, subfragile to fragile, moist, hygrophanous, nonstriate or edge at times with short, faint striations, at first surface \pm covered by a pale greenish white (Seafoam Green) or slightly more yellowish (near Sulphur Yellow) to dull pale yellow-buff veil, when older with some dull yellowish tones where faded, but mainly glabrescent, edge pale to somewhat yellowish from veil, color dark brown (rich Carob Brown to near Warm Sepia), fading in streaks, lighter brown (Verona Brown to Snuff Brown) when partly faded. Lamellae adnexed to deeply adnexed, moderately thick to thin, sometimes intervenose, subdistant to distant, at first reddish brown to dark brown (slightly Haematite Red, reddish Walnut
Brown, slightly Chocolate), then rich brown (Warm Sepia to Verona Brown) to lighter brown (Walnut Brown to Rood's Brown), edges always paler and eroded-fimbriate and whitish to faintly buffy colored. Stipe 40-110 mm long, 6-16 mm thick, equal to slightly ventricose, gradually tapered below, apex streaked watery brown or occasionally purple-vinaceous beneath a thin, white, silky covering, below watery brownish or paler brown (brown colors dull or somewhat reddish to vinaceous), lower surface with a \pm thin coating of whitish to yellowish white veil remnants, sometimes leaving a slight yellowish zone near midstipe, base white or watery gray to watery brown. Context $4-5 \mathrm{~mm}$ on disc, thin over lamellae, subfragile when expanded, watery and concolorous with the surface or lighter yellow brown, sometimes with distinct red-vinaceous tints, paler in age, and where faded above stipe apex, somewhat pinkish in places, solid in stipe, white to pale, streaked watery brown (Rood's Brown), or sometimes dull purple (light vinaceous purple), below watery brownish with some white streaks, stipe base cortex vinaceous brown or dull reddish brown (Pecan Brown), and center white with brownish tints. Odor and taste fungoid or slightly bitterish. Exsiccatae: pileus and lamellae dark brown to blackish; stipe faintly yellowish white where covered by universal veil, otherwise brownish to grayish brown; context light brown or dark brown to blackish.

UV fluorescence: strongly yellow stipe surface, universal veil on pileus, lamella edges, and entire context. $\mathrm{KOH}(10 \%)$ : reddish on universal veil.

Basidiospores 7.3-9.6(-10.5) $\times$ 4.5-5.5(-6) $\mu \mathrm{m}$, avg. $8.3 \times 4.9 \mu \mathrm{m}, \mathrm{Q}=1.5-1.8$, avg. $\mathrm{Q}=1.7$, ellipsoidal to amygdaloid, surface \pm coarsely verrucose, moderately to strongly dextrinoid. Basidia 4-spored, 31-34 × 7.5-9 $\mu \mathrm{m}$, clavate, colorless or with yellowish contents. Lamella trama hyphae \pm encrusted. Pileipellis: at least some veil hyphae on surface; epicutis hyphae cylindrical, colorless, yellowish or slightly brownish, 3-9(-13) $\mu \mathrm{m}$ wide, some encrusted; hypocutis not strongly developed, hyphae cylindrical to enlarged, colorless to brownish (6-)10-25(-31) $\mu \mathrm{m}$ wide, some encrusted; pileus trama hyphae brownish, commonly encrusted.

Ecology and distribution: In mixed conifer forests (Picea, Pseudotsuga, Abies, Tsuga, Larix, and/or Pinus; Alnus sometimes present), gregarious to caespitose. Basidiomes appear from late May into September. Known from Europe and western North America. In western North America, collected from the mountains of Washington, Oregon, Montana, Idaho, Wyoming, and Colorado. So far unreported from California.

Notes: Cortinarius colymbadinus is a widespread species, well known from Europe and North America. The names C. zinziberatus and C. isabellinus were applied to 
this species by some authors; however, the interpretation of these two names remains unclear, and therefore they cannot be applied at this time. Cortinarius colymbadinus is for the most part morphologically similar throughout its range, but in western North America younger specimens sometimes have vinaceous to purplish coloration in the stipe. It often produces basidiomes at the same time and location as C. ahsii, especially in the Rocky Mountains, but is generally less frequent than C. ahsii. Basidiospores of $C$. ahsii and C. colymbadinus are similar in shape and size, with overlap in length and width measurements. The UV reaction of the basidiomes is the easiest way to distinguish these taxa from one another. For Cortinarius ahsii, only the universal veil on the stipe and pileus surfaces and/or the stipe base are UV+ yellow, whereas the UV+ yellow reaction of $C$. colymbadinus is more extensive and includes the stipe surface, veil on the pileus surface, lamella edges, and entire context. In the ITS regions, C. colymbadinus differs from the other known western North American species of section Colymbadini, namely, from C. ahsii by 10 (1.9\%) and from C. vernalisierraensis by 14 (2.6\%) substitution and indel positions.

Specimens examined: AUSTRIA. Near Piller, conifers, 15 Sep 1988, J. Ammirati, JFA9773 (WTU), GenBank: KX882639. FINLAND. UUSIMAA: Porvoo, west side of the Lake Venjärvi, mesic to damp, mossy, grass-herb spruce forest (Picea abies) with some Populus tremula, Betula, and Pinus sylvestris, 17 Sep 2004, K. Liimatainen and T. Niskanen, 04-836, H6029678 (H), GenBank: KX882640. USA. MONTANA: Gallatin Co., Leverich Canyon, Pseudotsuga, Pinus contorta, 21 Jun 2012, E. Barge, EB0079 (MONT), GenBank: KX882641. WASHINGTON: Ferry Co., Karamip Road and Hwy 20, Picea, Pseudotsuga, Larix, scattered Pinus, Alnus, 23 Jun 1997, J. Ammirati, JFA12358 (WTU), GenBank: KX882642; Olympic National Park; Deer Park, Abies, 20 Jun 1991, J. Ammirati, JFA10261 (WTU). WYOMING: Teton Co., Two Oceans Mountain, mixed conifers, 27 Aug 1995, J. Ammirati, JFA11419 (WTU), GenBank: KX882643.

Additional specimens examined: See
SUPPLEMENTARY DATA.

Cortinarius vernalisierraensis Bojantchev, Ammirati, Niskanen \& Liimat, sp. nov. $\quad$ FIGS. 3E, F, 4C MycoBank MB817877

Typification: USA. CALIFORNIA: Nevada Co., north of Truckee, off Hwy 89, Pinus jeffreyi, 13 Jun 2010, D. Bojantchev, DBB33386 (holotype UC). Isotype WTU. GenBank: ITS = KX882652.
Etymology: The name of the species refers to its vernal fruiting in the California Sierra Nevada mountain range.

Differential diagnosis: Basidiomes medium to medium large; pileus light brown to darker brown with grayish hues towards margin, surface sometimes with whitish velar remnants; lamellae medium brown; stipe white, base white; universal veil yellowish. Under UV light, stipe base bright yellow to pinkish gold, flesh in base dull pinkish. Basidiospores avg. $8.5 \times 5 \mu \mathrm{m}$, avg. $\mathrm{Q}=1.65$. In ITS regions, differing in substitution and indel positions from C. ahsii by $8(1.5 \%)$ and from C. colymbadinus by $14(2.6 \%)$.

Description: Pileus 30-70 mm diam, convex to planoconvex, margin involute, remaining so in age, light to darker brown with grayish hues towards the margin, occasional whitish velar remnants present, hygrophanous, glabrous, innately fibrillose, often silky shiny. Lamellae sinuate, moderately crowded, 6-12 $\mathrm{mm}$ broad, medium brown at first, turning rusty brown as the spores mature, edges even. Stipe 60-120 mm long, 16-40 mm thick, cylindrical, white, finely fibrillose with a silky shine, base white. Universal veil yellowish, but not leaving distinct fragments at the base. Cortina white. Context white, stuffed, silky shiny. Odor earthy, indistinct. Taste mildly earthy. Exsiccatae: pileus shiny, black to brown; lamellae light brown to rusty brown; stipe pale with some blackish and brownish areas; base white to pale yellow; context pale and blackish.

UV fluorescence: stipe base bright yellow to pinkish gold; flesh in base dull pinkish. $\mathrm{KOH} \mathrm{(5 \% ):} \mathrm{negative} \mathrm{on}$ basidiome context and surface.

Basidiospores (7.7-)8-9.2(-9.6) × (4.3-)4.6-5.5(-5.5) $\mu \mathrm{m}$, avg. $8.6 \times 4.9 \mu \mathrm{m}, \mathrm{Q}=1.5-1.8$, avg. $\mathrm{Q}=1.65$, amygdaloid to ellipsoidal, moderately to strongly verrucose, moderately to strongly dextrinoid. Basidia 4-spored, 24-38 $\times 6-12 \mu \mathrm{m}$, clavate, colorless or with yellowish contents. Lamella trama hyphae \pm strongly encrusted. Pileipellis: veil hyphae typically covering the surface of the pileus margin; epicutis hyphae $2.5-10(-12) \mu \mathrm{m}$ wide, colorless to yellowish, smooth to encrusted; hypocutis not well developed, hyphae 3-15 $\mu$ m wide, yellow brown to brown, smooth to encrusted; pileus trama hyphae colorless to yellow brown, \pm strongly pigmented.

Ecology and distribution: Cortinarius vernalisierraensis most commonly occurs between 1050-1800 m, typically scattered to gregarious under conifers, including Pinus ponderosa, P. lambertiana, Pseudotsuga menziesii, Abies magnifica, A. concolor, and Calocedrus decurrens. It reproduces abundantly in late spring and early summer, during and soon after snow melt. It is so far only known from California, Sierra Nevada mountain range. 

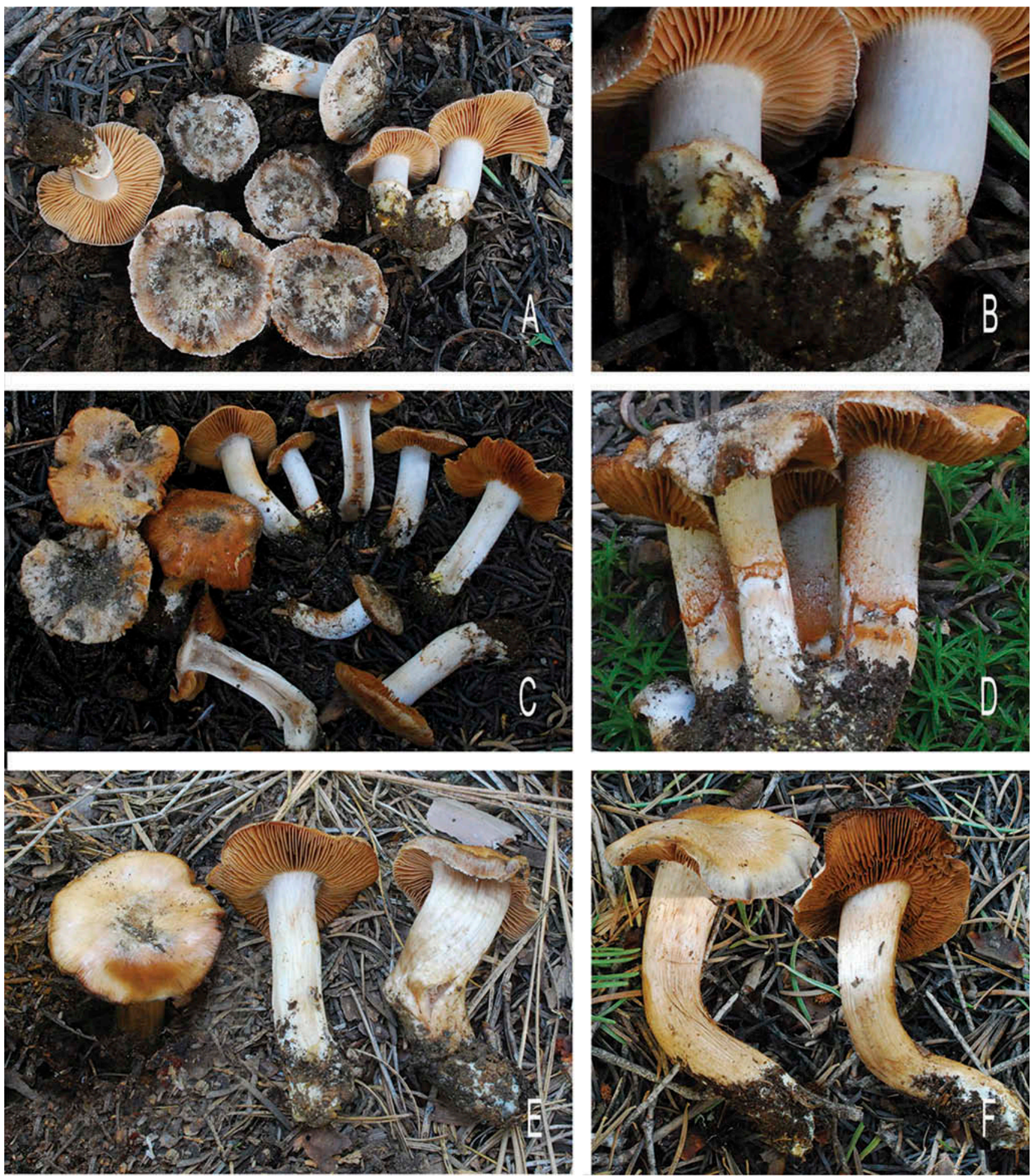

Figure 3. Species so far restricted to California. A-D. /Flavobasilis clade. A, B. Cortinarius vernalishastensis (DBB00243, type). C. C. rumoribrunsi (DBB16540, type). D. C. rumoribrunsi (DBB16555). E, F. Section Colymbadini. C. vernalisierraensis (DBB33386, type).

Notes: Cortinarius vernalsierraensis, a close relative of C. ahsii and C. colymbadinus, has been collected only in the Sierra Nevada mountain range, where it is fairly common. The long, relatively thick stipe in relation to the pileus diameter, and distinctive silky shine of the pileus surface remaining at maturity, helps to differentiate it from other related vernal members of the section. The UV fluorescence of Cortinarius vernalisierraensis is less extensive than in C. ahsii or C. colymbadinus in that the stipe base fluoresces bright yellow to pinkish gold 
and the flesh beneath is dull pinkish. The possible sister species based on our phylogenetic analysis, European $C$. nolaneiformis (Velen.) Dima, Niskanen \& Liimat., differs by over $20(3.7 \%)$ substitution and indel positions, but the relationship is weakly supported. This suggests that these two species are not closely related sister species.

Specimens examined: USA. CALIFORNIA: Tuolumne Co., Stanislaus National Forest, off Evergreen Road, Pinus ponderosa, Abies concolor, Pseudotsuga menziesii, 14 May 2009, D. Bojantchev, DBB15144 (UC), GenBank: KX882653; El Dorado Co., El Dorado National Forest, $0.1 \mathrm{mi}$, southeast of Icehouse Road, Pinus ponderosa, Abies concolor, Abies magnifica, Pseudotsuga menziesii, 22 May 2009, D. Bojantchev, DBB15338 (UC), GenBank: ITS $=$ KX882654.

Additional specimens examined: USA. See SUPPLEMENTARY DATA.

\section{Cortinarius, subgenus Telamonia, clade} /Flavobasilis.-Species in this clade are similar in appearance and general microscopic features to the species in section Colymbadini, but the four known species in this clade all have an orange UV fluorescent stipe base, in contrast with species in section Colymbadini from western North America, which all have a yellow UV reaction at the stipe base. The UV reaction on the pileus surfaces can sometimes be yellow in the /Flavobasilis clade. These species reproduce in spring and early summer and are currently only known from the mountains of western North America, associated with coniferous trees. The group is recovered as monophyletic but with weak bootstrap support.

Cortinarius bridgei Ammirati, Niskanen, Liimat, Bojantchev \& Fang, sp. nov.

FIGS. 2F, 4D

MycoBank MB817878

Typification: USA. WASHINGTON: Chelan Co., Alder Creek Trail, Pseudotsuga, Abies, 16 May 2009, J. Ammirati, JFA13326 (holotype WTU). Isotype K. GenBank: ITS $=$ KX882655.

Etymology: Named for William Bridge Cooke, known to mycologists as "Bridge," who was the first mycologist to study snowbank fungi in western North America.

Differential diagnosis: Basidiomes medium size; pileus red-brown to light brown with a thin covering of yellow veil; lamellae light to medium brown; stipe white with watery brown streaks, base pale yellow to orange yellow; universal veil yellow. Under UV light, stipe base intensely orange, universal veil on the pileus and stipe surface pale yellow. Basidiospores avg. $8 \times 4.5$ $\mu \mathrm{m}$, avg. $\mathrm{Q}=1.75$. In ITS regions, differing in substitution and indel positons from C. flavobasilis by $6(1.1 \%)$, from C. vernalishastensis by $8(1.5 \%)$, and from C. rumoribrunsi by 9 (1.7\%).

Description: Pileus $26-80 \mathrm{~mm}$ diam, obtuse-umbonate to broadly convex then obtusely convex to planoconvex or uplifted, margin slightly incurved to decurved, then plane to slightly up-turned, moist, hygrophanous, edge pale and faintly striate or nonstriate, margin with a thin covering of pale yellowish universal veil, sometimes covering disc, color on disc dark reddish brown to blackish red-brown, margin rich reddish brown to dark redbrown but soon fading in streaks and patches to redbrown, light medium brown (Sayal Brown), and pale brown. Lamellae crowded to close or subdistant, adnexed to deeply adnexed with a decurrent line, moderately thick, light to pale medium brown, mature rich medium brown, edges paler and slightly eroded. Stipe 40-70 mm long, 8-16(-27) mm thick above, equal, then tapered at base, surface shiny, white silky fibrillose with pale to light watery brown streaks, at base more watery brown (brown colors often with slight reddish or pinkish tones), lower stipe in places covered by a thin yellow universal veil, sometimes ending above in a slight zone, stipe base pale yellow to orange yellow. Context of pileus whitish to watery brown (concolorous with surface), or slightly reddish brown, in stipe white to whitish with light watery brown streaks (reddish to pinkish tones may be mixed in), sometimes hollow above, with yellow line sometimes present along base, becoming mostly brownish in age. Odor pleasant, mushroom-like. Taste radishlike or mushroom-like. Exsiccatae: pileus brown and black; lamellae light brown to dark brown; stipe pale to slight brownish or black in older specimens, base yellow to orange; context pale to brownish or blackish.

UV fluorescence: basal mycelium intensely bright orange, the universal veil on the pileus and stipe very pale yellow. $\mathrm{KOH}(40 \%)$ : instantly bright red on stipe base.

Basidiospores (6.5-)7.2-8.8(-9.5) $\times 4-4.5(-5) \mu \mathrm{m}$, avg. $8 \times 4.4 \mu \mathrm{m}, \mathrm{Q}=1.6-1.9$, avg. $\mathrm{Q}=1.75$, amygdaloid to somewhat ellipsoidal, moderately to more coarsely verrucose, slightly to moderately dextrinoid. Basidia 4-spored, 26.5-31 × 7.5-10 $\mu \mathrm{m}$, clavate, colorless or with yellowish contents. Lamella trama hyphae smooth or finely encrusted. Pileipellis: veil hyphae typically covering the surface of the pileus margin; epicutis hyphae 3-10 $\mu \mathrm{m}$ wide, colorless or more often yellowish or brownish, smooth to encrusted; hypocutis moderately well developed, hyphae 7.5-21 $\mu \mathrm{m}$ wide, colorless to brownish with some areas more yellow brown pigmented, smooth to encrusted; pileus trama brownish to colorless. 
Ecology and distribution: Occurs with conifers, including Pseudotsuga menziesii, Abies concolor, A. grandis, A. lasiocarpa, A. magnifica, Larix, Pinus, and Tsuga; with Thuja plicata sometimes present. Caespitose to gregarious in soil and needles. Fruiting from spring into early July, depending on elevation and rate of snow melt. Occurs from California north into Washington and eastward into the Rocky Mountains.

Notes: Cortinarius bridgei is very similar morphologically to C. flavobasilis and both have a UV+ orange fluorescent stipe base. They are sympatric throughout their range and often co-occur in the same habitat. These two species can be separated from one another by basidiospore length and width, the spores of C. bridgei (avg. $8 \times 4.4 \mu \mathrm{m}$ ) being smaller than those of $C$. flavobasilis (avg. $9.4 \times 5 \mu \mathrm{m}$ ).

Specimens examined: USA. CALIFORNIA: Shasta Co., off Hwy 89, Abies concolor, A. magnifica, Pseudotsuga menziesii, Pinus ponderosa, 20 Jun 2010, D. Bojantchev, DBB33534, GenBank: KX882656, DBB33567, GenBank: KX882657, DBB33603, GenBank: KX882658 (all UC); Siskiyou Co., east of Mt. Shasta, off Military Pass Road, Abies magnifica var. shastensis, A. concolor, Pseudotsuga menziesii, Calocedrus decurrens, 10 Jun 2011, D. Bojantchev, DBB47798 (UC), GenBank: KX882659; Tuolumne Co., Yosemite National Park., off Hwy 120, Pinus ponderosa, Abies concolor, A. magnifica, Pseudotsuga menziesii, 25 Jun 2010, D. Bojantchev, DBB33921 (UC), GenBank: KX882660. WASHINGTON: Chelan Co., Alder Creek Trail, Pseudotsuga, Abies, 16 May 2009, J. Ammirati, JFA13328 (WTU), GenBank: KX882661; Fish Lake area, Pseudotsuga, Abies, and Pinus, 20 May 2007, L. Fang, 2007-05-20-02 (WTU), GenBank: KX882662; Kittitas Co., Table Mountain area, Pseudotsuga, Abies, Pinus contorta, Picea, Larix, Tsuga, 27 May 2007, L. Fang, 2007-05-27-01(WTU), GenBank: ITS = KX882663.

Additional specimens examined: See SUPPLEMENTARY DATA.

Cortinarius flavobasilis M.M. Moser \& O.K. Miller ex Peintner, Kuhnert-Finkernagel, Cripps \& Ammirati, sp. nov.

FIG. 4E

MycoBank MB817879

= "Cortinarius flavobasilis" nomen nudem, M.M. Moser \& O.K. Miller, Cortinarius species from the snowbanks in the Rocky Mountains. Unpublished manuscript, 23 p. (2002).

Type: USA. Yellowstone National Park: West slopes of Mt. Washburn, Abies, Picea, Pinus, 30 Jul 1983, M.M.
Moser, IB19830164 (holotype IB). GenBank: ITS = KX882664.

Etymology: Based on the "yellow" color of the exterior stipe base.

Differential diagnosis: Basidiomes small to medium size; pileus pale ochraceous to pinkish brown or darker brown, glabrous or with a thin covering of pallid veil fibrils; lamellae pale ochre brown; stipe white, base yellow; universal veil white to yellow. Under UV light, stipe base deep orange, universal veil on stipe and pileus surface yellow. Basidiospores avg. $9.5 \times 5 \mu \mathrm{m}$, avg. $\mathrm{Q}=1.8$. In ITS regions, differing in substitution and indel positions from $C$. bridgei by 6 (1.1\%), from $C$. vernalishastensis by 7 (1.3\%), and from C. rumoribrunsi by $8(1.5 \%)$.

Description: Pileus $15-25 \mathrm{~mm}$ diam, at first hemispheric, later planoconvex, margin sometimes undulate, not translucently striate, smooth, hygrophanous, sometimes greasy in appearance, colors varying from pale ochraceous, pale incarnate brown to deeper brown disc darker brownish, sometimes with red-brown areas, slightly radially innately fibrillose, glabrous or with thin covering of pallid veil fibrils. Lamellae adnate to slightly sinuate or broadly emarginated, moderately close, pale ocher-brown, becoming dark reddish brown (5YR4/6), edges concolorous, moderately eroded. Stipe 25-45 mm long, 4-7 $\mathrm{mm}$ thick, cylindrical, sometimes curved, sometimes longitudinally grooved, white, base lemon yellow, universal veil white in freshly collected specimens, later becoming lemon yellow, forming irregular, incomplete belts or single patches, these becoming tocher-brown. Context in pileus very pale brownish, in stipe stuffed to tubular hollow, whitish with paler brownish pith. Odor fungoid to slightly pungent. Taste mild. Exsiccatae: pileus brown to blackish in places; lamellae light brown to dark brown or rust brown; stipe pale to whitish with some brownish to grayish brown tones, base yellow to slightly orange yellow; context pale to whitish, sometimes slightly brownish in pileus.

UV fluorescence: stipe base deep orange and yellow where covered by universal veil. $\mathrm{KOH}(30 \%)$ : universal veil and stipe base red.

Basidiospores (7.5-)8.4-10.6(-11) × 4.5-5.8 $\mu \mathrm{m}$, avg. $9.4 \times 5, \mathrm{Q}=1.7-1.9$, avg. $\mathrm{Q}=1.8$, amygdaloid to ellipsoidal, coarsely verrucose, strongly dextrinoid. Basidia 4-spored, 30-33 × 7.5-8.5 $\mu \mathrm{m}$, clavate, colorless or with yellowish contents. Lamella trama hyphae slightly to strongly encrusted. Pileipellis: veil hyphae typically covering the surface of the pileus margin; epicutis with upper layer \pm colorless and lower layer 


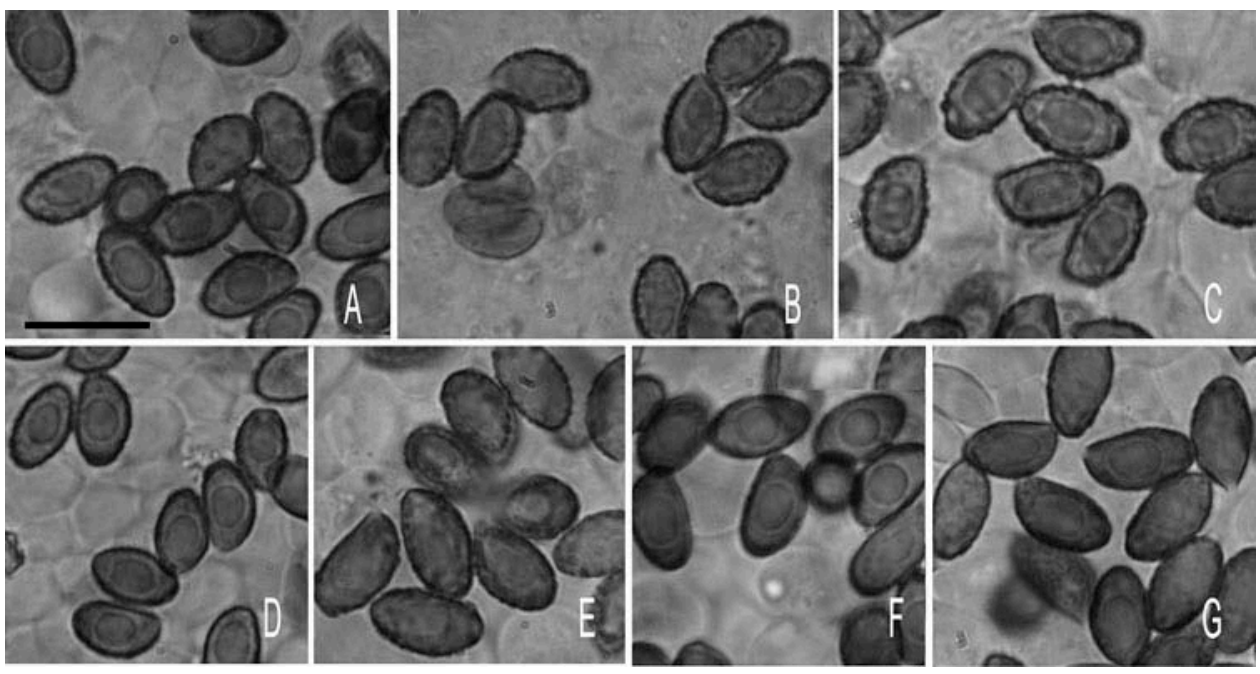

Figure 4. Spores. A-C. Section Colymbadini. A. Cortinarius ahsii (LF2007-05-27-02). B. C. colymbadinus (JFA12357). C. C. vernalisierraensis (DBB3386). D-G. /Flavobasilis. D. C. bridgei (LF2007-05-27-01). E. C. flavobasilis (JFA10278). F. C. rumoribrunsi (DBB16540). G. C. vernalishastensis (DBB0243). Bar $=10 \mu \mathrm{m}$, refers to all photos.

brownish, hyphae 3-7 $\mu \mathrm{m}$ wide, colorless, yellowish or brownish, slightly to strongly encrusted; hypocutis moderately well developed, hyphae (3-)8-15 $\mu \mathrm{m}$, mostly brownish, \pm encrusted; pileus trama hyphae colorless to slightly brownish.

Ecology and distribution: In mixed conifer forests of Abies, Picea, Pinus, and/or Tsuga, low- to mid- or highelevation subalpine forests. Often beginning to reproduce basidiomes about $2-3$ wk after snow melt at higher elevations. Occurs from California northward into Washington and eastward into the Rocky Mountains.

Notes: Cortinarius flavobasilis is similar in appearance and UV fluorescence to C. bridgei, from which it is distinguished by its larger basidiospores. These species are sympatric throughout their range and co-occur in similar habitats. Cortinarius flavobasilis was long ago noted as new by Meinhard Moser and Orson Miller, who collected extensively in the Rocky Mountains, hence the authorship Cortinarius flavobasilis M.M. Moser \& O.K. Miller ex Peintner, Kuhnert-Finkernagel \& Cripps. Cortinarius bridgei and C. flavobasilis share an orange UV fluorescent stipe base with C. rumoribrunsi and $C$. vernalishastensis. These latter two species have basidiospores that are similar in size to those of $C$. flavobasilis. Cortinarius vernalishastensis has a distinct volva-like sock at the base of the stipe, and C. rumoribrunsii has considerably more yellow pigment in the hyphae and the basidia of the exsiccatae when mounted in $3 \% \mathrm{KOH}$ than other species in the /Flavobasilis clade.

Specimens examined: USA. MONTANA: Park Co., New World District, Abies, Picea, Pinus albicaulis, 11 Jul 2005, C. Cripps, CLC2113 (MONT), GenBank:
KX882665. WASHINGTON: Chelan Co., Smith Brook, 0.25 miles from Hwy 2, Abies, Tsuga, $27 \mathrm{Jul}$ 1991, J. Ammirati, JFA10278 (WTU), GenBank: KX882666; Snohomish Co., Barlow Pass, Abies, Tsuga, 1 May 1992, L. Norvell, JFA10454 (WTU), GenBank: ITS $=$ KX882667.

Additional specimens examined: See SUPPLEMENTARY DATA.

Cortinarius rumoribrunsi Bojantchev, Ammirati, Niskanen \& Liimat, sp. nov.

FIGS. 3C, D, 4F

MycoBank MB817880

Typification: USA. CALIFORNIA: Yosemite National Park, off Hwy 120, Pinus ponderosa, Abies concolor, A. magnifica, Pseusdotsuga menziesii, 20 Jun 2009, D. Bojantchev, DBB16540 (holotype UC). Isotype WTU. GenBank: ITS = KX882668.

Etymology: The "Bruns rumor" after the popular saying by Prof. Tom Bruns regarding cryptic species - "without a sequenced voucher, it is only a rumor."

Differential diagnosis: Basidiomes medium size; pileus brown, \pm covered with whitish velar remnants; lamellae medium brown; stipe white with grayish streaks, base yellow; universal veil white. Under UV light, stipe base orange, no yellow fluorescence. Basidiospores avg. $8.5 \times 5.0 \mu \mathrm{m}$, avg. $\mathrm{Q}=1.85$. In ITS regions, differing in substitution and indel positions from C. flavobasilis by 8 (1.5\%), from C. bridgei by 9 (1.7\%), and from C. vernalishastensis by $11(2.0 \%)$.

Description: Pileus $30-80 \mathrm{~mm}$ diam, convex to planoconvex, margin involute, frequently upturned in age, brown with whitish velar remnants sometimes covering the entire pileus, surface smooth to 
glossy, distinctly fibrillose, inconspicuously hygrophanous with occasional radial streaks. Lamellae sinuate, moderately crowded, 7-13 mm broad, medium brown at first, turning rusty brown as the spores mature; edges even. Stipe $30-80 \mathrm{~mm}$ long, 12-25 mm wide, cylindrical, slightly curved at the base, white with faint vertical grayish streaks, base covered yellowish velar remnants. Universal veil white, partially covering the lower stipe, often leaving an evanescent annular zone between the base and midstipe. Cortina white. Context white, developing longitudinal cavities of pale, watery gray discoloration. Odor earthy. Taste mild earthy. Exsiccatae: pileus light brown to black; lamellae brown to rust brown; stipe pale to brownish or blackish, base pale yellow to orange; context pale to brownish or blackish.

UV fluorescence: orange on stipe base, no yellow. $\mathrm{KOH}(5 \%)$ : negative on basidiome context and surface.

Basidiospores (7.5-)8-9.5(-10) $\times(4-) 4.5-5.3(-5.5)$ $\mu \mathrm{m}$, avg. $8.7 \times 4.8 \mu \mathrm{m}, \mathrm{Q}=1.7-2$, avg. $\mathrm{Q}=1.85$, amygdaloid to ellipsoidal, surface slightly to moderately or more coarsely verrucose, moderately to strongly dextrinoid. Basidia 4-spored, 24-32 × 5-9 $\mu \mathrm{m}$, clavate, some colorless but more commonly with rich yellow contents (best viewed in $\mathrm{KOH}$ ). Lamella trama hyphae encrusted. Pileipellis: a layer of veil hyphae typically covering the surface of the pileus margin; epicutis hyphae colorless, yellowish or yellow brown, 3-10 $\mu \mathrm{m}$ wide, some encrusted; hypocutis not well developed, hyphae 4-21 $\mu \mathrm{m}$ wide, colorless, not encrusted; pileus trama hyphae colorless to brownish.

Ecology and distribution: Under conifers, including Pinus ponderosa, Abies concolor, A. magnifica, and Pseudotsuga menziesii, at elevation ca. $2100 \mathrm{~m}$. Scattered to subcaespitose. Fruits abundantly late spring to early summer in the mountains of California, during and soon after snow melt.

Notes: Cortinarius rumoribrunsi is a member of the rich vernal mycota of snowbank species in the Cascade-Sierra Mountains. The exsiccatae of this species have an UV+ orange stipe base, which it shares with C. flavobasilis, C. vernalishastensis, and C. bridgei. Mounts in $3 \% \mathrm{KOH}$ of the exsiccatae; hyphae and basidia of $C$. rumoribrunsi have considerably more yellow pigment than in other species treated here. It also appears somewhat smaller in stature than the other members of this clade. Cortinarius rumoribrunsi has not been reported from north of Mt. Lassen and appears to be a species of the southern Sierra Nevada mountain range based on current collections.

Specimens examined: USA. CALIFORNIA: Yosemite National Park, off Hwy 120, Pinus ponderosa, Abies concolor, A. magnifica, Pseusdotsuga menziesii, 20 Jun 2009, D. Bojantchev, DBB16555 (UC), GenBank: ITS = KX882669.

Cortinarius vernalishastensis Bojantchev, Ammirati, Niskanen \& Liimat, sp. nov.

FIGS. 3A, B, 4G MycoBank MB817881

Typification: USA. CALIFORNIA: Siskiyou Co., east of Mt. Shasta, off Military Pass Road, Abies magnifica var. shastensis, A. concolor, Pseudotsuga menziesii, and Calocedrus decurrens, 1 Jun 2008, D. Bojantchev, DBB00243 (holotype UC). Isotype WTU. GenBank: ITS $=$ KX882670.

Etymology: The name of the species refers to Mt. Shasta, California, near where it was collected, and the spring fruiting pattern.

Differential diagnosis: Basidiomes medium to medium large size; pileus brown to dark grayish brown, \pm covered with white velar remnants; lamellae medium brown; stipe white, base yellow; universal veil white, leaving distinct volva-like membranous sock at the base. Under UV light, stipe base pale orange. Basidiospores avg. $8.5 \times 5$ $\mu \mathrm{m}$, avg. $\mathrm{Q}=1.85$. In ITS regions, differing in substitution and indel positions by 7 (1.3\%) from C. flavobasilis, 8 (1.5\%) from C. bridgei, and by 11 (2.0\%) from C. rumoribrunsi.

Description: Pileus 50-100 mm diam, convex to planoconvex, margin involute, frequently upturned at age, inconspicuously hygrophanous with occasional radial streaks towards the margins, brown to dark grayish brown with whitish velar remnants sometimes covering most of the pileus. Lamellae sinuate, moderately crowded, 8-14 mm broad, medium brown at first, turning rusty brown as the spores mature, edges even. Stipe $40-110 \mathrm{~mm}$ long, 16-28 mm wide, cylindrical, slightly abruptly bulbous at the base when young, white, stipe base yellowish. Universal veil leaving a distinct volva-like membranous sock at the base, later collapsing, often leaving an evanescent annular zone between the base and the midstipe. Cortina white. Context white, often pale watery gray at the base. Odor earthy. Taste mild earthy. Exsiccatae: pileus brownish to grayish brown, pale in some areas; lamellae brown to rusty brown; stipe brownish and blackish to grayish with some pale areas, base pale to dull whitish; context pale, brownish or black in older specimens.

UV fluorescence: light pale orange on stipe base. $\mathrm{KOH}(5 \%)$ : negative on pileus surface and context. 
Basidiospores (7.5-)8.1-9.4(-10) $\times(4-) 4.4-5.4(-5.5)$ $\mu \mathrm{m}$, avg. $8.7 \times 4.9 \mu \mathrm{m}, \mathrm{Q}=1.7-2$, avg. $\mathrm{Q}=1.85$, amygdaloid to ellipsoidal, surface slightly to moderately verrucose, moderately to more strongly dextrinoid. Basidia 4spored, 22-36 $\times 5-10 \mu \mathrm{m}$, clavate, colorless or with yellowish contents. Lamella trama hyphae smooth to slightly encrusted. Pileipellis: a layer of veil hyphae typically covering the surface of the pileus margin; epicutis hyphae 2-10 $\mu \mathrm{m}$ wide, colorless or yellowish to yellow brown, smooth to encrusted; hypocutis not well developed, hyphae 6-22 $\mu \mathrm{m}$ wide, yellow brown to brown, \pm encrusted; pileus trama hyphae colorless to brownish.

Ecology and distribution: Under conifers, including Abies magnifica var. shastensis, A. concolor, Pseudotsuga menziesii, and Calocedrus decurrens. Scattered to subcaespitose. Reproduces abundantly in late spring and early summer in the mountains of California during and soon after snow melt.

Notes: Cortinarius vernalishastensis is one of the members of the rich vernal mycota of snowbank Telamonia in the Cascade-Sierra Mountains. The pileus has persistent grayish brown to brown colors. There is a whitish universal veil layer covering the pileus margin, and the veil also forms a distinct white volva-like sock at the base, a feature not found in other species treated here. The stipe base of fresh basidiomes is yellow. It has an UV+ orange stipe base, which it shares with C. flavobasilis, $C$. bridgei, and C. rumoribrunsi.

\section{KEY TO SPECIES OF CORTINARIUS IN SECTION COLYMBADINI AND CLADE /FLAVOBASILIS FROM WESTERN NORTH AMERICA}

1. Under UV light, the basidiome context, lamella edges, universal veil, and/or stipe base yellow ............................................................. 2

1'. Under UV light, the stipe base distinctly light orange to intensely orange, surface of stipe and pileus sometimes UV+ yellow 4

2. Under UV light, the basidiome context, lamella edges, universal veil, and stipe base yellow; pileus dark brown, \pm covered with yellowish veil remnants; lamellae reddish brown to rich brown; stipe often with watery brown to vinaceous brown streaks, base watery brown to white; universal veil whitish to yellowish; basidiospores on avg. $8.5 \times 5$ $\mu \mathrm{m}$ C. colymbadinus

2'. Under UV light, only the universal veil and/or the stipe base yellow to pinkish gold 3

3. Under UV light, universal veil and/or stipe base yellow; pileus dark reddish brown to dark brown, sometimes with greenish yellow veil covering; lamellae yellow brown to rich brown; stipe white to buff or brown, base white to slightly yellowish; universal veil greenish yellow to yellow; basidiospores on avg. $8.5 \times 5 \mu \mathrm{m}$ C. ahsii

3'. Under UV light, stipe base bright yellow to pinkish gold; pileus light to dark brown with grayish tones, occasionally with white universal veil remnants; lamellae medium brown; stipe white with white base; universal veil yellowish, not leaving distinct remnants on stipe base; basidiospores on avg. $8.5 \times 5 \mu \mathrm{m}$ C. vernalisierraensis

4. Under UV light, stipe base orange; reddish brown to light brown, often \pm covered with yellowish universal veil remnants; lamellae light to pale brown; stipe white with watery brown streaks, base yellow to orange yellow; universal veil pale yellow; basidiospores on avg. $8.0 \times 4.5 \mu \mathrm{m}$. C. bridgei

4'. Basidiospores on avg. larger, 8.5-9.5 $\times 5 \mu \mathrm{m}$........... 5

5. Universal veil white, forming a distinct volvalike sock at the base of the stipe; stipe white with yellow base; basidiospores on avg. $8.5 \times$ $5 \mu \mathrm{m}$ C. vernalishastensis

5'. Universal veil not forming a volva-like sock at the base of the stipe

6. Pileus brown with whitish universal veil covering; lamellae medium brown; stipe white with grayish streaks, base yellow; universal veil white on lower stipe; basidiospores on avg. $8.5 \times$ $5.0 \mu \mathrm{m}$...................................... C. rumoribrunsi

6'. Pileus ochraceous to incarnate brown, brown, or red-brown, glabrous or with thin covering of pallid fibrils; lamellae pale ochre brown to reddish brown; stipe white with base yellow; universal veil white to lemon yellow; basidiospores on avg. $9.5 \times$ $5 \mu \mathrm{m}$ C. flavobasilis

\section{DISCUSSION}

Morphological characteristics, the patterns of UV fluorescence, and molecular data taken together support the recognition of seven well-defined snowbank species of Cortinarius subgenus Telamonia associated with coniferous trees in the mountains of western North America. Three of them, C. ahsii, C. colymbadinus, and C. vernalisierraensis, belong to the section Colymbadini sensu stricto. The remaining four species, C. bridgei, C. flavobasilis, C. rumoribrunsi, and C. vernalishastensis, form one group, tentatively named /Flavobasilis, but the placement of this clade remains unresolved. A threshold value of $99 \%$ for delimiting species in this section is in 
concordance with the findings of Garnica et al. (2016) for the majority of species of Cortinarius.

Cortinarius colymbadinus occurs in western North America and Europe, whereas all other species appear to occur only in western North America. To date, C. bridgei and C. flavobasilis are widespread and known from the Rocky Mountains and the mountains of California, Oregon, and Washington. Cortinarius colymbadinus and C. ahsii are among the more widespread western species but have not been recorded from California. In contrast, C. rumoribrunsi, C. vernalishastensis, and C. vernalisierraensis have only been found in the central mountains of California. It is expected that more extensive surveys in the southern Rocky Mountains and the central and southern Oregon mountains will expand the known distributions of these species. Some species, such as $C$. colymbadinus and $C$. ahsii, are known to occur in western Canada, and others likely occur in the Canadian Rockies, but we have limited data on collections from this region of North America. None, including C. colymbadinus, are known from eastern North America.

The species treated here occur primarily in habitats that receive moderate to heavy snow fall from autumn, winter, and early spring storms. This includes low- to mid-elevation as well as high-elevation subalpine conifer forests. In the Rocky Mountains, the Cascade-Sierra Mountains, as well as the Olympic Mountains, potential host trees for these taxa include species of Abies, Larix, Picea, Pinus, Pseudotusga, and Tsuga. In the southwestern Oregon and California mountains, Picea is rather rare and does not extend into the Sierra Nevada mountain range, whereas Larix is absent from southwestern Oregon or California forests. In these regions, which includes the Siskiyou Mountains, higher-elevation conifer forests are composed primarily of Abies, Pinus, and Pseudotusga host species, with Tsuga mertensiana at higher elevations. Our collection data to date show differences in the distributions of several species. Cortinarius colymbadinus, a widespread species, occurs in Europe and western North America with a broad range of conifer tree hosts, but it has not been reported from the mountains of California. Cortinarius rumoribrunsi, C. vernalishastensis, and C. vernalisierraensis also are known only from California. Cortinarius vernalisierraensis was collected under Pinus jeffreyi, whereas C. vernalishastensis was collected under Abies and Pseudotsuga, and C. rumoribrunsi with Pinus ponderosa, Abies concolor, A. magnifica, and Pseudotsuga menziesii. Cortinarius ahsii, a common species in the Rocky Mountains and Pacific Northwest, occurs with a variety of conifer hosts and has not been recorded from
California. It is likely that host trees and other factors have an influence on the distributions of the species treated here; however, much more extensive sampling of forests, including sequence data from roots and soil materials, will be needed to determine if these species are sympatric within their ranges. Finally, most snowbank Cortinarius species are endemic to western North America and their conservation status should be considered.

UV reactions can be used to distinguish the two clades and, to a lesser extent, the species presented here. The species in section Colymbadini sensu stricto have yellow UV fluorescence with the exception of European C. uraceomajalis, which sometimes exhibits an orange UV fluorescent stipe base (Dima et al. 2014). In C. colymbadinus, most of the basidiome is yellow UV fluorescent. In C. ahsii, yellow UV fluorescence is restricted to the universal veil on the lower stipe pileus surface and stipe base. In C. vernalisierraensis, stipes of exsiccatae are bright yellow to pinkish gold under UV light. Orange UV fluorescence in the stipe base is the key character separating Colymbadini from /Flavobasilis. The species in /Flavobasilis, C. bridgei, C. flavobasilis, C. rumoribrunsi, and C. vernalishastensis all have a light orange to intense orange UV fluorescent stipe base. In addition, the universal veil on the stipe and pileus surface of $C$. flavobasilis and C. bridgei may exhibit some yellow UV fluorescence. Most likely, the yellow UV fluorescence is a consequence of the presence of the pigment leprocybin, but this has not been determined for certain in all species (Gill and Steglich 1987; Peintner et al. 2004).

There is some variation in basidiospore size and surface ornamentation; however, these characters must be used in combination with others to distinguish species from one another. Species included in this study have a moderately developed pileus hypocutis, but this character is not useful for defining species, because it is similar among species and varies somewhat with the maturity of the basidiome.

Pigmentation of lamella trama tissue and the hymenium of the species considered here does not appear to be very helpful in delimiting species. Perhaps the more significant difference is in $3 \% \mathrm{KOH}$ mounts of $C$. rumoribrunsi, where the hyphae and the basidia have considerably more yellow pigment than in other species. Encrusting pigment on pileus and lamella trama hyphae also is not particularly helpful for separating species, although C. colymbadinus often has strongly encrusted pileus trama hyphae and the lamella trama hyphae of $C$. ahsii can be strongly encrusted as well. The application of $3-10 \% \mathrm{KOH}$ to yellow universal veil 
tissue and stipe base of fresh basidiomes typically gives a red to pink reaction in many species, but this has not been well tested in this group of species.

\section{ACKNOWLEDGMENTS}

Karl Soop contributed a collection of C. ahsii from Colorado, and Ed Barge provided sequences and photos of C. colymbadinus. Some of the initial phylogenetic studies of these species were done by Lily Fang, University of Washington, Seattle.

\section{FUNDING}

Partial support for this project was provided by the D. E. Stuntz Memorial Foundation.

\section{ORCID}

Tuula Niskanen (D) http://orcid.org/0000-0003-1479-5548

Kare Liimatainen (D) http://orcid.org/0000-0002-5422-2384

Cathy Cripps (D) http://orcid.org/0000-0002-3402-2422

\section{LITERATURE CITED}

Ammirati JF, Barlow T, Seidl M, Ceska O, Berbee M, Harrower E. 2012. Cortinarius parkeri, a new species from the Pacific Northwest of North America. Botany 90:327-335.

Ammirati JF, Smith AH. 1977. Studies in the genus Cortinarius, III: section Dermocybe, new North American species. Mycotaxon 5:381-397.

Bojantchev D. 2013. Cortinarius of California: eight new species in subgen. Telamonia. Mycotaxon 123:375-402.

Cooke W. 1944. Notes on the ecology of the fungi of Mount Shasta. The American Midland Naturalist 31:237-249.

Cooke W. 1955. Subalpine fungi and snowbanks. Ecology $36: 124-130$

Cripps C. 2009. Snowbank fungi revisited. Fungi 2:47-53.

Dima B, Liimatainen K, Niskanen T, Kytövuori I, Bojantchev D. 2014. Two new species of Cortinarius, subgenus Telamonia, sections Colymbadini and Uracei, from Europe. Mycological Progress 13:867-879.

Edgar RC. 2004. MUSCLE: multiple sequence alignment with high accuracy and high throughput. Nucleic Acids Research 32:1792-1797.

Galtier N, Gouy M, Gautier C. 1996. SEAVIEW and PHYLO_WIN: two graphic tools for sequence alignment and molecular phylogeny. Bioinformatics 12:543-548.

Gardes M, Bruns TD. 1993. ITS primers with enhanced specificity for basidiomycetes. Application to the identification of mycorrhizae and rusts. Molecular Ecology 2:113-118.

Garnica S, Schön ME, Abarenkov K, Riess K, Liimatainen K, Niskanen T, Balint D, Soop K, Froeslev T, Jeppesen $\mathrm{T}$, Peintner U, Kuhnert-Finkernagel R, Brandrud TE, Saar G, Oertel B, Ammirati J. 2016. Determining threshold values for barcoding fungi: lessons from Cortinarius (Basidiomycota), a highly diverse and widespread ectomycorrhizal genus. FEMS Microbiology Ecology 92: fiw045.
Gill M, Steglich W. 1987. Pigments of fungi (Macromycetes). Progress in the Chemistry of Organic Natural Products 51:1317.

Kornerup A, Wanscher JH. 1962. Reinhold color atlas. New York, New York: Reinhold Publishing. 224 p.

Knudsen H, Vesterholt J. 2012. Funga nordica: agaricoid, boletoid, clavarioid, cyphelloid and gastroid genera. Copenhagen, Denmark: Nordsvamp. 1083 p.

Liimatainen K, Niskanen T, Dima B, Kytövuori I, Ammirati JF, Frøslev T. 2014. The largest type study of Agaricales species to date: bringing identification and nomenclature of Phlegmacium (Cortinarius, Agaricales) into the DNA era. Persoonia 33:98-140.

McKnight KH. 1975. A new species of Cortinarius (Telamonia) from the Rocky Mountains. Beiheft Nova Hedwigia 51:177-182, 2 pls.

Miller OK Jr. 1965. Snowbank mushrooms in the Three Sisters wilderness area. Mazama 47:8-41.

Moser MM. 1993. Studies on North American Cortinarii III. The Cortinarius flora of dwarf and shrubby Salix associations in the alpine zone of the Wind River Mountains, Wyoming, USA. Sydowia 45:275-306.

Moser MM. 2002. Studies in the North American Cortinarii. 7. New and interesting species of Cortinarius subgen. Telamonia from the Rocky Mountains. Feddes Repertorium Specierum Novarum Regni Vegetabilis 113:48-62.

Moser MM. 2004. Subalpine conifer forests in the Alps, the Altai, and the Rocky Mountains: a comparison of their fungal populations. In: Cripps C, ed. Fungi in forest ecosystems: systematics, diversity and ecology. Bronx, New York: New York Botanical Garden Press. p. $151-158$.

Moser MM, Ammirati JF. 1999. Studies in North American Cortinarii V. New and interesting Phlegmacia from Wyoming and the Pacific Northwest. Mycotaxon 72:289321.

Moser MM, McKnight KH, Ammirati JF. 1995. Studies on North American Cortinarii I. New and interesting taxa from the greater Yellowstone area. Mycotaxon 75:301-346.

Munsell. 1992. Munsell soil color charts. Newburgh, New York: Munsell Color. 16 p.

Niskanen T, Liimatainen K, Ammirati JF. 2013. Five new Telamonia species (Cortinarius, Agaricales) from western North America. Botany 91:478-485.

Peintner U, Moncalvo JM, Vilgalys R. 2004. Toward a better understanding of the infrageneric relationships in Cortinarius (Agaricales, Basidiomycota). Mycologia 96:1042-1058.

Redhead SA, Ammirati J, Norvell L, Seidl M. 2000. Notes on western North American snowbank fungi. Mycotaxon 76:321-328.

Ridgway R. 1912. Color standards and color nomenclature. Washington, DC: Author. 43 p, LIII pl.

Seidl MT. 2000. Cortinarius vernicosus: a new spring species of subgenus Myxacium from western Washington. Mycotaxon 76:113-124.

Smith AH. 1944. New and interesting Cortinarii from North America. Lloydia 7:163-235.

Smith AH. 1975. A field guide to western mushrooms. Ann Arbor, Michigan: University of Michigan Press. 280 p.

Stamatakis A. 2014. RAxML version 8: a tool for phylogenetic analysis and post-analysis of large phylogenies. Bioinformatics 30:1312-1313. 
Thiers B. (continuously updated). Index herbariorum: a global directory of public herbaria and associated staff. New York Botanical Garden's Virtual Herbarium. [cited 2006 Jan 15]. Available from: http://sweetgum.nybg.org/ih/ Thiers HD, Smith AH. 1969. Hypogeous Cortinarii. Mycologia 61:526-536.
White TJ, Bruns T, Lee S, Taylor JW. 1990. Amplification and direct sequencing of fungal ribosomal RNA genes for phylogenetics, In: Innis, MA, Gelfand DH, Sninsky JJ, White TJ, eds. PCR protocols: a guide to the methods and applications. New York, New York: Academic Press. p. $315-322$. 